\title{
ANTIOXIDANT ACTIVITY OF BLACKBERRY (Rubus sp.) GENOTYPES FROM THE SOUTHERN REGION OF BRAZIL
}

\author{
GABRIELA ELISA HIRSCH * \\ MÁRCIA VIZZOTTO ** \\ ANA LUCIA ABOY *** \\ AMÉLIA TERESINHA HENRIQUES **** \\ TATIANA EMANUELLI *****
}

\begin{abstract}
The antioxidant activity and bioactive compounds of different blackberry fruit genotypes from the major Brazilian producer region (three cultivars and four selections) were evaluated and compared to the Cherokee cultivar. Phenolic and anthocyanic extracts were obtained and evaluated for each fruit genotype. The phenolic extracts of selections 02/96 and 07/001 presented higher antioxidant activity than those of cultivars in most assays. This activity was partially correlated to the higher amount of total phenolics in these samples. Thus, the phenolic compounds are probably the major responsible for the antioxidant activity in the diphenyl-2-picrylhydrazyl radical scavenging assay (DPPH), ferric reducing antioxidant power (FRAP) assay and thiobarbituric acid reactive substances (TBARS) assay. Quercetin seems to be responsible for the antioxidant activity of blackberry phenolic extracts in the $\beta$-carotene bleaching assay. Concerning anthocyanic extracts, the selection 02/96 and Cherokee cultivar from harvest 2007 had higher antioxidant activity than the other genotypes in most assays. Anthocyanins appear to be the major responsible for the antioxidant activity of anthocyanic extracts in the DPPH and FRAP assays, although ascorbic acid also contributed to the DPPH antioxidant activity. Selection 02/96 appears to have higher antioxidant activity than the commercial cultivars cultivated in the southern Brazil and appears to be promising for nutritional and health purposes.
\end{abstract}

KEY-WORDS: FRUIT EXTRACT; ANTIOXIDANTS; POLYPHENOLS; ANTHOCYANINS; ASCORBIC ACID.

* Mestre em Ciência e Tecnologia de Alimentos do Programa de Pós-graduação em Ciência e Tecnologia dos Alimentos, Centro de Ciências Rurais, Universidade Federal de Santa Maria (UFSM), Santa Maria, RS, Brasil (e-mail: ehgabis@yahoo.com.br).

** Pós-doutora em Ciência e Tecnologia dos Alimentos, Pesquisadora, Embrapa Clima Temperado, Pelotas, RS, Brasil (e-mail: vizzotto@cpact.embrapa.br).

*** Mestre em Ciências Farmacêuticas, Pesquisadora, Faculdade de Farmácia, Universidade Federal do Rio Grande do Sul (UFRGS), Porto Alegre, RS, Brasil (e-mail: analuciaaboy@yahoo.com.br).

**** Doutora em Ciências Físicas-Químicas, Professora Titular, Faculdade de Farmácia, UFRGS, Porto Alegre, RS, Brasil (e-mail: amelia@farmacia.ufrgs.br).

***** Doutora em Ciências Biológicas (Bioquímica), Professora Associada III, Departamento de Tecnologia e Ciência dos Alimentos, UFSM, Santa Maria, RS, Brasil (e-mail: tatiemanuelli@gmail.com). 


\section{INTRODUCTION}

Blackberry crop was introduced in Brazil in the 70's by the Brazilian Agricultural Research Corporation (Embrapa) - Temperate Climate (ANTUNES, 2002). Thereafter, the genetic improvement program of Embrapa has developed various cultivars adapted to the Southern Region of Brazil, including Guarani, Caingangue, Xavante and Tupy. This last one ranks among the most influential fresh market blackberry varieties, because it is cultivated in Brazil and in Mexico, where it is largely exported to the United States of America (USA). Due to its adequate climate characteristics (temperate climate) Rio Grande do Sul was the first state in Brazil to produce blackberries and it is still the major blackberry producer (ANTUNES, 2002).

Blackberry fruits are good sources of natural antioxidants such as anthocyanins and phenolic acids (KOCA \& KARADENIZ, 2009), but little is known about the presence and antioxidant activity of these compounds in genotypes adapted and grown in the state of Rio Grande do Sul (Brazil).

Phenolic compounds or polyphenols have the ideal structure for scavenging free radicals and are considered more effective antioxidants than vitamins $C$ and $E$. Flavonoids are the largest group of polyphenols in foods (BRAVO, 1998). Anthocyanins are flavonoid pigments particularly abundant in red fruits, such as blackberries (SIRIWOHARN et al., 2004). Anthocyanins are widely studied because of their antioxidant effects and potential benefits for human health (PRIOR, 2003).

The regular consumption of blackberries may contribute to an important intake of antioxidant polyphenols (HASSIMOTTO et al., 2008). However, the antioxidant activity of fruits and vegetables varies considerably. Various factors including genotype (REYES-CARMONA et al., 2005; SIRIWOHARN et al., 2004), growing temperature, growing season, maturity at harvest and environmental stress (PARR \& BOLWELL, 2000) may explain the differences in the antioxidant activity among cultivars. Although many studies evaluated the phenolic content or the antioxidant activity of blackberries (CUEVAS-RODRÍGUEZ et al., 2010; ELISIA et al., 2007; SEERAM et al., 2006), a low number of studies correlated the antioxidant activity of blackberries (Rubus $s p$.) with their content of bioactive compounds (KOCA \& KARADENIZ, 2009; SARIBURUN et al., 2010). The only study with this approach on Brazilian blackberry genotypes had a limited antioxidant assessment (only one type of assay) and has evaluated fruits grown in a tropical climate region, which is not the major producer region (HASSIMOTTO et al., 2008). In addition, there is no study on the antioxidant activity or bioactive compounds in blackberries (Rubus $s p$.) grown in the major Brazilian producer region, which has a temperate climate (Rio Grande do Sul - Brazil).

Polyphenol-rich fruits have a great research interest since high intake of polyphenolic compounds was associated to a reduced risk of oxidative stress-related disorders like cardiovascular diseases and cancer (PRIOR, 2003). In addition, data on the antioxidant activity and bioactive compounds of different fruit genotypes may be useful for genetic improvement programs to select those varieties with higher nutritional value. Thus, the objective of this study was to evaluate the antioxidant activity and bioactive compounds of extracts from blackberry fruit genotypes produced in the state of Rio Grande do Sul. The fruits were from cultivars and selections developed at Embrapa Temperate Climate and have been studied to yield cultivars adapted to the Southern Region of Brazil. For comparison purposes the Cherokee cultivar was also evaluated.

\section{MATERIAL AND METHODS}

\subsection{REAGENTS}

6-Hydroxy-2,5,7,8-tetramethylchroman-2-carboxylic acid (Trolox $\left.{ }^{\circledR}\right)$, 2,4,6-tris(2-pyridyl)-1,3, 5-triazine (TPTZ), 2,2-diphenyl-2-picrylhydrazyl hydrate (DPPH), Folin-Ciocalteu reagent, gallic acid, 
beta-carotene, linoleic acid, ellagic acid, caffeic acid, chlorogenic acid, 3,4-dihydroxybenzoic acid, ferulic acid, para-coumaric acid, syringic acid and ascorbic acid were obtained from Sigma Chemical Co. (St. Louis, MO, USA). Quercetin was acquired from Jassem Chemical (Beerse, Belgium) and Vanillic acid from Fluka Chemical (Buchs, Switzerland).

\subsection{FRUIT SAMPLES}

Samples of blackberry (Rubus sp.) cultivars Guarani, Cherokee and Tupy and Embrapa selections 03/001, 07/001 and 02/96 from the harvest 2007 and samples of cultivars Xavante and Cherokee and Embrapa selection 99 from harvest 2009 were collected at Embrapa Temperate

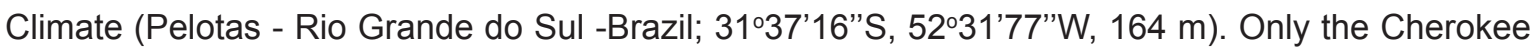
genotype is not originary from Brazil, but it is widely adapted to the studied region. Each sample lot was a mixture of completely ripe fruits from five plants of the same genotype. Three independent lots were collected (approximately $400 \mathrm{~g}$ each one), frozen at $-18^{\circ} \mathrm{C}$ and transported to the laboratory. The fruits were fully homogenized in a home multiprocessor and stored at $-18^{\circ} \mathrm{C}$ until analysis.

\subsection{DETERMINATION OF PHENOLIC CONTENT}

The extraction of phenolic compounds followed the method of Escarpa \& González (2001) with some modifications (PELLEGRINI et al., 2007). The homogenized sample $(4 \mathrm{~g})$ was extracted in an ultrasonic bath at room temperature in the absence of light with an aqueous solution consisting of $800 \mathrm{~mL}$ methanol and $50 \mathrm{~mL}$ formic acid per liter. The samples were sequentially extracted with $6 \mathrm{~mL}$ of solvent for $1 \mathrm{~h}, 6 \mathrm{~mL}$ for $30 \mathrm{~min}$ and $3 \mathrm{~mL}$ for $30 \mathrm{~min}$. After each extraction, the extracts were filtered under vacuum. The combined filtrate was brought to a final volume of $25 \mathrm{~mL}$ with the solvent and stored at $-18^{\circ} \mathrm{C}$ until required for analysis.

Total phenolic content of extracts was determined using Folin-Ciocalteu reagent at $740 \mathrm{~nm}$ (SINGLETON \& ROSSI, 1965) and gallic acid $\left(50-600 \mathrm{mg}^{\cdot \mathrm{L}^{-1}}\right)$ for the calibration curve $\left(r^{2}=0.995\right)$.

To determine the composition of phenolics the phenolic extracts were centrifuged at $2,500 \times \mathrm{g}$ and the supernatants were analyzed in a Waters HPLC system (2695 model) using a Luna C18(2) $100 \AA \AA$ (250 x $4.60 \mathrm{~mm}$, particle size $3 \mu \mathrm{m}$ ) column (Phenomonex, Torrance, CA, USA)

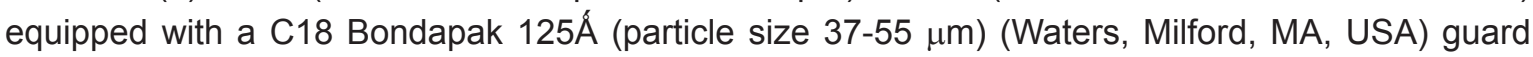
column and a photodiode array detector (Waters 996 Series). The chromatographic conditions were: $0.5 \mathrm{~mL} \cdot \mathrm{min}^{-1}$ flow rate, $10 \mu \mathrm{L}$ injection volume, mobile phase comprised of solvent $\mathrm{A}, 0.5 \%$ formic acid ( $\mathrm{pH} 2.4)$, and solvent $\mathrm{B}, 100 \%$ acetonitrile, and detection at $371 \mathrm{~nm}$. The elution profile was 0 min, $10 \%$ B; $1-30$ min, linear gradient from $10 \%$ to $30 \%$ B; $30-55$ min, linear gradient from $30 \%$ to $100 \%$ B, $55-66$ min, $100 \%$ B; followed over 8 minutes to return to the initial conditions (10\% B). The identification of compounds was performed by the combined use of chromatographic behavior, cochromatography with authentic standards and DAD spectra with authentic standards (caffeic acid, chlorogenic acid, 3,4-dihydroxybenzoic acid, ellagic acid, ferulic acid, gallic acid, para-coumaric acid, quercetin, syringic acid, vanillic acid). Quercetin was quantified using a seven-point calibration curve (1- $\left.20 \mathrm{mg} \cdot \mathrm{L}^{-1}, r^{2}=0.996\right)$. The limit of quantification was $1.90 \mathrm{mg}^{\cdot \mathrm{kg}^{-1}}$ fruit and the limit of detection was $0.63 \mathrm{mg}^{\prime} \mathrm{kg}^{-1}$ fruit.

\subsection{DETERMINATION OF ANTHOCYANIN CONTENT}

The extraction of anthocyanins was performed as described by Lees \& Francis (1972). The fruits were homogenized in the extracting solvent containing $95 \%$ ethanol and $1.5 \mathrm{~mol} \cdot \mathrm{L}^{-1} \mathrm{HCl}$ $85: 15 \mathrm{v} / \mathrm{v}$. The proportion sample/extracting solvent was $0.8 \mathrm{~g} \cdot \mathrm{mL}^{-1}$. The sample was stored for $12 \mathrm{~h}$ at $4^{\circ} \mathrm{C}$, filtered under vacuum and the residue was exhaustingly washed with the extracting solvent 
for complete removal of pigments. The filtrates were collected in a volumetric flask, brought to $50 \mathrm{~mL}$ with the extracting solvent, left to stand in the absence of light for $2 \mathrm{~h}$ at room temperature and the absorbance was measured at $535 \mathrm{~nm}$. Total anthocyanin content was calculated using the extinction coefficient $\varepsilon^{1 \%}=98.2$ at $535 \mathrm{~nm}$.

\subsection{DETERMINATION OF ASCORBIC ACID CONTENT}

The ascorbic acid content of sample extracts was assessed as described by SánchezMata et al. (1999) with some modifications. Extracts were filtered $(0.22 \mu \mathrm{m}$ Millipore filter, Bedford, Md., USA) and analyzed using an Intralab HPLC system (5100 model) coupled to an UV-visible detector (Intralab 5100) and reverse phase Microsorb-MW C18 column (4.6 x $250 \mathrm{~mm}$, particle size $5 \mu \mathrm{m}$ ) (Varian). The chromatographic conditions were: $10 \mu \mathrm{L}$ injection volume, $0.9 \mathrm{~mL} \cdot \mathrm{min}^{-1}$ flow rate, sulfuric acid $0.01 \%(\mathrm{pH} \mathrm{2.8)}$ as the mobile phase, $8 \mathrm{~min}$ run time, detection at $245 \mathrm{~nm}$. Ascorbic

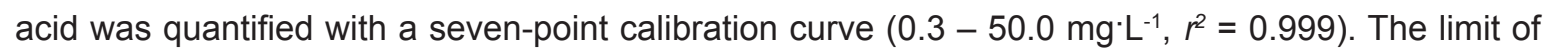
quantification was $0.35 \mathrm{mg}^{\cdot} \mathrm{kg}^{-1}$ fruit and the limit of detection was $0.07 \mathrm{mg}^{\cdot} \mathrm{kg}^{-1}$ fruit.

\subsection{EVALUATION OF ANTIOXIDANT ACTIVITY}

Four different methods were used to evaluate the antioxidant activity of phenolic and anthocyanic extracts from blackberries: the DPPH radical scavenging assay (BRAND-WILLIAMS, CUVELIER \& BERSET, 1995), the ferric-reducing antioxidant power (FRAP) (BENZIE \& STRAIN, 1996); the $\beta$-carotene bleaching assay (MILLER, 1971) and the inhibition of lipid oxidation assessed by TBARS (MOLLER et al., 1999). Since the anthocyanic extracts had a purple color, appropriate blank tubes were conducted containing the extracts to check if it would mask the spectrophotometric measurements of antioxidant activity. At the extract concentrations evaluated only the $\beta$ carotene bleaching assay was affected. Thus, this assay was not performed for the anthocyanic extracts.

\subsubsection{DPPH radical scavenging assay}

The DPPH assay was conducted as described by Brand-Williams, Cuvelier \& Berset (1995). DPPH solution was diluted until $1.10 \pm 0.02$ absorbance at $515 \mathrm{~nm}$ was obtained. The extract $(0.05 \mathrm{~mL})$ was mixed with $1.9 \mathrm{~mL} \mathrm{DPPH}$ solution and absorbance was assessed against a blank. Trolox was used for the calibration curve $\left(0.01-0.08 \mathrm{mmol}^{\cdot} \mathrm{L}^{-1}\right)$ and the results were expressed as mmol of trolox equivalents per $1 \mathrm{~kg}$ of fruit.

\subsubsection{FRAP assay}

The method of Benzie \& Strain (1996) was used. The sample $(40 \mu \mathrm{L})$ was mixed with $1.2 \mathrm{~mL}$ of $\mathrm{Fe}^{3+}-\mathrm{TPTZ}$ reagent and incubated at $37^{\circ} \mathrm{C}$ during $15 \mathrm{~min}$. The absorbance of the reduced $\mathrm{Fe}^{2+}-\mathrm{TPTZ}$ complex was taken at $593 \mathrm{~nm}$. Trolox was used for the calibration curve (100 $500 \mu \mathrm{mol} \cdot \mathrm{L}^{-1}$ ) and the results were expressed as mmol of trolox equivalents per $1 \mathrm{~kg}$ of fruit.

\subsection{3 $\beta$-Carotene bleaching assay}

This method is based on the ability of extracts to decrease the oxidative losses of $\beta$-carotene in a model system of substrate co-oxidation: $\beta$-carotene/linoleic acid (MILLER, 1971). The extract $(100 \mu \mathrm{L})$ was mixed with $2.9 \mathrm{~mL}$ of the $\beta$-carotene solution and the absorbance at $470 \mathrm{~nm}$ was measured immediately and after $2 \mathrm{~h}$ of incubation at $50^{\circ} \mathrm{C}$. A control sample with $100 \mu \mathrm{L}$ of extracting solution of total phenolics instead of the sample extract was also analyzed for antioxidant activity. Antioxidant activity was calculated as percent inhibition relative to the control. 


\subsubsection{Inhibition of lipid oxidation assessed by TBARS}

The ability of extracts from blackberry to inhibit lipid oxidation in homogenates of fish flesh was assessed as previously described by Moller et al. (1999) with some modifications. Fish flesh was ground, mixed with distilled water $(1: 3 \mathrm{v} / \mathrm{v})$ and homogenized in an Ultra Turrax. Fish homogenate was mixed with phenolic (0.5-60.0 $\mathrm{\mu g}$ of total phenolics per $1 \mathrm{~mL}$ of fish homogenate) or anthocyanic extracts $(0.12-30.0 \mu \mathrm{g}$ of total anthocyanins per $1 \mathrm{~mL}$ of fish homogenate). Blank tubes in which the vehicle of each extract type was added were used as controls instead of the extract. Ferrous sulfate $\left(0.2 \mathrm{mmol} \cdot \mathrm{L}^{-1}\right)$ was added to all tubes to accelerate the oxidation. Tubes were incubated at $50^{\circ} \mathrm{C}$ for $90 \mathrm{~min}$, centrifuged and the supernatant was used to determine lipid oxidation as thiobarbituric acid reactive substances (TBARS). The inhibition of lipid oxidation was calculated as percent relative to control.

\subsubsection{Calculation of the inhibitory concentration $50\left(\mathrm{IC}_{50}\right)$}

The $\mathrm{IC}_{50}$ for $\beta$-carotene bleaching and lipid oxidation (concentration inhibiting $50 \%$ of reaction) was determined by non-linear regression analysis, and compared by evaluating their confidence intervals (MOTULSKY \& CHRISTOPOULOS, 2004). The $I C_{50}$ values were expressed as $\mu \mathrm{g}$ of total phenolics or anthocyanins per $1 \mathrm{~mL}$ of reaction assay medium.

\subsection{STATISTICAL ANALYSIS}

All measurements were carried out in triplicate. Results were analyzed by one-way analysis of variance (ANOVA) followed by Tukey's test when appropriate $(p<0.05)$. The relationship between antioxidant compounds (phenolics, quercetin, anthocyanins or ascorbic acid) and antioxidant activity was evaluated by Pearson's correlations $(p<0.05)$. Some antioxidant compounds had a significant correlation with each other, which could lead to a bias when evaluating their correlations with the antioxidant activity. To overcome this problem, the partial correlation was used, because it allows the assessment of the relationship that remains between two variables, after controlling for a third variable (SPIEGEL \& STEPHENS, 2011).

\section{RESULTS}

The antioxidant activity of blackberry fruits, determined by FRAP and DPPH assays, was expressed as equivalent of the standard antioxidant trolox, which is a hydrosoluble analog of vitamin E. In the harvest 2007, phenolic extracts of selections 07/001 and 02/96 showed the highest ferric reducing antioxidant power followed by selection 03/001 $=$ Tupy $>$ Guarani $=$ Cherokee, whereas in the harvest 2009 Xavante cultivar > selection $99>$ Cherokee $(p<0.05$; Table 1). Selections 07/001 and 02/96 also showed the highest DPPH radical scavenging capacity followed by Guarani cultivar > selection 03/001 $=$ Cherokee $=$ Tupy, in the harvest $2007(p<0.05)$, whereas in 2009 no significant difference was found among genotypes (Table 1). No significant difference was found between Cherokee cultivars from harvest 2007 and 2009 in the FRAP or DPPH assays (Table 1).

The antioxidant activity of phenolic extracts was also assessed using the $\beta$-carotene bleaching assay (Fig. 1A). $\beta$-carotene oxidation was inhibited by all genotypes in a dose-dependent manner $(p<0.05)$. However, Guarani cultivar had the highest inhibitory potency in this test (lowest I $\mathrm{C}_{50}$ value) in the harvest 2007, whereas in the harvest 2009 Xavante cultivar had the highest inhibitory potency $(p<0.05$; Table 1$)$. There was no statistical difference in the $\beta$-carotene bleaching assay between Cherokee fruits from harvest 2007 and 2009 (Table 1). 
TABLE 1 - ANTIOXIDANT ACTIVITY OF BLACKBERRY

PHENOLIC EXTRACTS

\begin{tabular}{|c|c|c|c|c|}
\hline \multirow{2}{*}{ Samples } & \multirow{2}{*}{$\begin{array}{c}\text { FRAP } \\
\left(\mathrm{mmol}^{\prime} \mathrm{kg}^{-1}\right)\end{array}$} & \multirow{2}{*}{$\begin{array}{c}\text { DPPH } \\
\left(\mathrm{mmol} \cdot \mathrm{kg}^{-1}\right)\end{array}$} & \multicolumn{2}{|c|}{$\mathrm{IC}_{50}\left(\mu \mathrm{g} \cdot \mathrm{mL}^{-1}\right)$} \\
\hline & & & $\begin{array}{c}\text { Betacarotene } \\
\text { bleaching }\end{array}$ & TBARS \\
\hline \multicolumn{5}{|c|}{ Harvest year 2007} \\
\hline Selection 07/001 & $41.8 \pm 2.0^{a}$ & $8.1 \pm 0.5^{a}$ & $3.5^{\mathrm{a}}(2.0-6.1)$ & $19.5^{\mathrm{bc}}(10.8-35.3)$ \\
\hline Selection 03/001 & $27.8 \pm 0.5^{b}$ & $2.2 \pm 0.1^{c}$ & $6.3^{a}(3.0-13.3)$ & $7.9^{\mathrm{cd}}(4.5-13.9)$ \\
\hline Selection $02 / 96$ & $47.9 \pm 1.2^{\mathrm{a}}$ & $7.6 \pm 0.2^{\mathrm{a}}$ & $5.5^{\mathrm{a}}(2.5-12.0)$ & $1.0^{\mathrm{d}}(0.1-7.2)$ \\
\hline Guarani & $16.7 \pm 2.8^{c}$ & $4.7 \pm 0.1^{\mathrm{b}}$ & $0.7^{\mathrm{b}}(0.5-1.0)$ & $44.3^{\mathrm{ab}}(22.1-88.9)$ \\
\hline Tupy & $28.4 \pm 2.2^{b}$ & $1.9 \pm 0.2^{c}$ & $4.2^{\mathrm{a}}(1.6-11.3)$ & $78.0^{\mathrm{a}}(40.2-151.4)$ \\
\hline Cherokee & $18.1 \pm 3.1^{c}$ & $2.0 \pm 0.2^{c}$ & $5.7^{a}(2.0-16.0)$ & $40.7^{\mathrm{ab}}(21.7-76.2)$ \\
\hline \multicolumn{5}{|c|}{ Harvest year 2009} \\
\hline Cherokee & $16.2 \pm 0.4^{c}$ & $2.4 \pm 0.2$ & $8.3^{a}(3.9-17.5)$ & $40.2(17.9-90.0)$ \\
\hline Selection 99 & $27.5 \pm 0.5^{b}$ & $2.2 \pm 0.1$ & $7.7^{\mathrm{a}}(3.6-15.9)$ & $>60.0$ \\
\hline Xavante & $37.6 \pm 0.0^{a}$ & $1.5 \pm 0.1$ & $1.8^{\mathrm{b}}(0.9-3.4)$ & $52.3(33.8-81.0)$ \\
\hline
\end{tabular}

FRAP and DPPH values are means \pm standard deviations $(n=3)$ expressed as mmoL of trolox equivalent per $1 \mathrm{~kg}$ of fruit. The $\mathrm{IC}_{50}$ values are means (confidence intervals) $(n=3)$ expressed as $\mu \mathrm{g}$ of phenolics per $1 \mathrm{~mL}$ of extract. DPPH: 1 , 1-diphenyl-2picrylhydrazyl; FRAP: ferric reducing antioxidant power; TBARS: thiobarbituric acid reactive substances. Values that have no common superscript letter (a,b,c,d) within the same column and in the same harvest year are significantly different $(p<0.05)$. No significant difference was found between Cherokee cultivars from harvest 2007 and 2009.

It was also measured the ability of extracts from different blackberry genotypes to inhibit iron-induced lipid oxidation in a fish flesh homogenate (Fig. 1B), which was assessed as TBARS formation. All genotypes inhibited TBARS formation in a dose-dependent manner. The harvest 2007, selection 02/96 had the highest antioxidant activity in the TBARS assay (lowest IC $\mathrm{C}_{50}$ value) followed by selection 03/001 and 07/001. Tupy had the lowest antioxidant activity (highest IC ${ }_{50}$ value) and the other genotypes had intermediate activity (Table 1). There was no statistical difference in the TBARS formation among genotypes in the harvest 2009, or between Cherokee fruits from harvest 2007 and 2009 (Table 1).

To identify the major compounds responsible for the antioxidant activity of phenolic extracts it was evaluated the extract composition and its correlation with the antioxidant activity. The total phenolic content was significantly different among the genotypes (Table 2). In the harvest 2007, selections $07 / 001$ and $02 / 96$ had higher total phenolic content than selection 03/001, Guarani and Cherokee cultivars, whereas Tupy cultivar had intermediate value $(p<0.05)$. However, in the harvest 2009 there was no difference in the content of phenolics among genotypes. As observed in the antioxidant assays, it was found no significant difference in the total phenolic content between Cherokee fruits from harvest 2007 and 2009.

In the HPLC analysis of the genotypes harvested in 2007, ellagic acid, vanillic acid, and quercetin were identified, but ellagic acid and vanillic acid were found only at trace amounts. For this reason only quercetin was quantified. In addition to these phenolic compounds, other large peaks were found in the chromatogram, but unfortunately they could not be identified (data not shown). Guarani cultivar had the highest content of quercetin among the genotypes studied and selection $03 / 001$ had the lowest content, whereas the other genotypes showed intermediate values (Table 2; $p<0.05)$. 

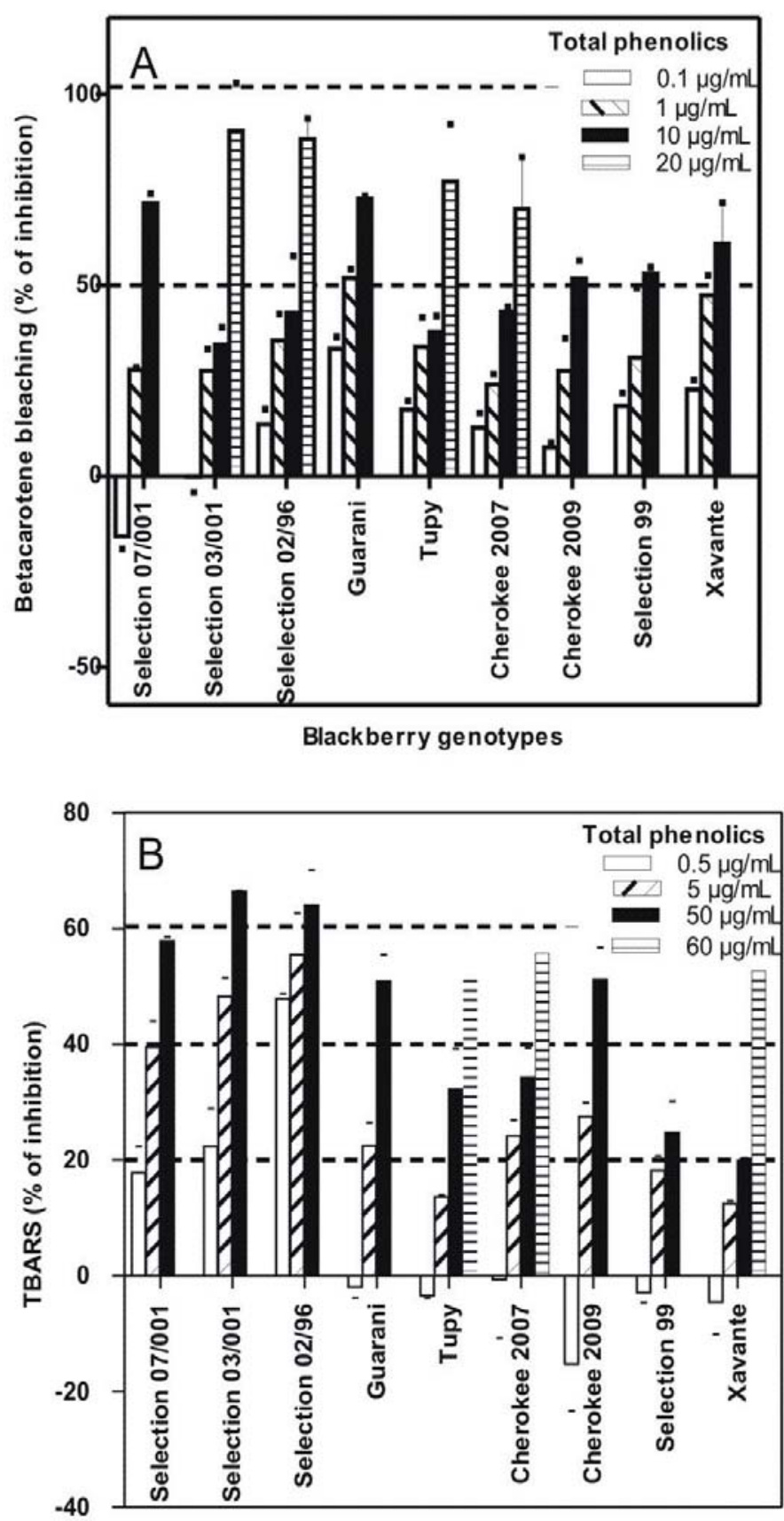

Blackberry genotypes

FIGURE 1 - INHIBITION OF BETACAROTENE BLEACHING (A) AND LIPID OXIDATION IN FISH HOMOGENATE (B) BY BLACKBERRY PHENOLIC EXTRACTS

Results are expressed as means \pm standard deviations $(n=3)$. Two-way ANOVA revealed a significant phenolic concentration $x$ blackberry genotype interaction on the inhibition of $\beta$-carotene bleaching in the harvest 2007 and 2009 and on the inhibition of lipid oxidation in the harvest 2007 , whereas only a significant effect of phenolic concentration was found on lipid oxidation in the harvest $2009(p<0.05)$. The $I_{50}$ values are shown in Table 1.

Although this study focused mainly on the polyphenols of blackberries, some ascorbic acid could have been extracted along with the phenolic compounds. To assess which compounds 
contribute to the antioxidant activity of the blackberry extracts, it was also evaluated the content of ascorbic acid in these extracts. In general, ascorbic acid was found at small amount in the phenolic extracts (Table 2), usually lower than the limit of quantification ( $0.35 \mathrm{mg}^{-\mathrm{kg}^{-1}}$ fruit). However, it was possible to quantify the ascorbic acid contents of selection 99 and Xavante cultivar, which were higher than that of the Cherokee cultivar in the harvest 2009 ( $p<0.05$; Table 2). No significant difference was found in the ascorbic acid content between Cherokee fruits from harvest 2007 and 2009.

\section{TABLE 2 - COMPOSITION OF BLACKBERRY PHENOLIC EXTRACTS}

\begin{tabular}{|c|c|c|c|}
\hline \multirow{2}{*}{ Samples } & \multicolumn{2}{|c|}{ Phenolic content } & \multirow{2}{*}{$\begin{array}{c}\text { Ascorbic acid } \\
\left(\mathrm{mg}^{\left.-k^{-1}\right)}\right.\end{array}$} \\
\hline & $\begin{array}{l}\text { Total phenolics } \\
\qquad\left(\mathrm{g}^{\cdot} \mathrm{kg}^{-1}\right)\end{array}$ & $\begin{array}{l}\text { Quercetin } \\
\left(\mathrm{mg}^{\prime} \mathrm{kg}^{-1}\right)\end{array}$ & \\
\hline \multicolumn{4}{|c|}{ Harvest year 2007} \\
\hline Selection 07/001 & $9.9 \pm 0.6^{a}$ & $26.0 \pm 4.9^{\mathrm{bc}}$ & $<\mathrm{LOQ}$ \\
\hline Selection $03 / 001$ & $4.5 \pm 1.0^{\mathrm{b}}$ & $17.3 \pm 2.5^{c}$ & $<L O Q$ \\
\hline Selection 02/96 & $10.2 \pm 0.8^{a}$ & $28.4 \pm 4.9^{\mathrm{bc}}$ & $<\mathrm{LOQ}$ \\
\hline Guarani & $4.4 \pm 1.1^{b}$ & $60.4 \pm 2.7^{a}$ & $<L O Q$ \\
\hline Tupy & $6.4 \pm 1.0^{\mathrm{ab}}$ & $38.8 \pm 0.1^{b}$ & $<L O Q$ \\
\hline Cherokee & $5.2 \pm 2.6^{b}$ & $25.9 \pm 3.0^{\mathrm{bc}}$ & $<\mathrm{LOQ}$ \\
\hline \multicolumn{4}{|c|}{ Harvest year 2009} \\
\hline Cherokee & $3.4 \pm 1.0$ & ------ & $<\mathrm{LOQ}^{\mathrm{b}}$ \\
\hline Selection 99 & $3.6 \pm 0.7$ & ------ & $0.65 \pm 0.01^{a}$ \\
\hline Xavante & $4.0 \pm 0.8$ & ----- & $0.74 \pm 0.11^{\mathrm{a}}$ \\
\hline
\end{tabular}

Results are means \pm standard deviations $(n=3)$. Total phenolics are expressed as $\mathrm{g}$ of gallic acid per $1 \mathrm{~kg}$ fruit. Values that have no common superscript letter $(a, b, c)$ within the same column and in the same harvest year are significantly different $(p<0.05)$. No significant difference was found between Cherokee cultivars from harvest 2007 and 2009. LOQ = Limit of quantification $\left(0.35 \mathrm{mg} \cdot \mathrm{kg}^{-1}\right)$.

It was observed a positive correlation between total phenolic content and the antioxidant activity assessed by the $\operatorname{FRAP}\left(r^{2}=0.746 ; p<0.05\right)$ and $\mathrm{DPPH}\left(r^{2}=0.785 ; p<0.05\right)$ assays. However, no significant correlation was found between quercetin content and the antioxidant activity, assessed by the DPPH or FRAP assays. Although no significant correlation was found between total phenolic content and the antioxidant activity assessed by the $\beta$-carotene bleaching method, there was a strong negative correlation between quercetin content and the $\mathrm{IC}_{50}$ values for $\beta$-carotene bleaching $\left(r^{2}=-0.844 ; p<0.05\right)$. A negative correlation was observed between total phenolic content and the $\mathrm{IC}_{50}$ values for the TBARS assay $\left(r^{2}=-0.565 ; p<0.05\right)$. However, no significant correlation was found between quercetin and $I_{50}$ values for the TBARS assay. The ascorbic acid content of phenolic extracts had no significant correlation with any of the antioxidant assays evaluated $(p>0.05)$.

The antioxidant capacity of the anthocyanic extracts was evaluated only by the FRAP, DPPH and TBARS assays (Table 3 ) because the intense color of these extracts interfered in the $\beta$-carotene bleaching assay. In the FRAP assay, the selections 07/001, 03/001 and 02/96 and the Cherokee cultivar had greater ferric reducing power than the other samples in the harvest $2007(p<0.05)$. In 
the harvest 2009, Xavante cultivar had higher FRAP values than Cherokee, whereas selection 99 had intermediate value $(p<0.05)$. In the DPPH assay, no significant difference was found among genotypes. However, both the FRAP and the DPPH values were higher for the Cherokee cultivars from 2007 compared to $2009(p<0.05)$.

\section{TABLE 3 - ANTIOXIDANT ACTIVITY OF BLACKBERRY ANTHOCYANIN EXTRACTS}

\begin{tabular}{lccc}
\hline Samples & $\begin{array}{c}\text { FRAP } \\
\left(\mathrm{mmol}^{\prime} \mathrm{kg}^{-1}\right)\end{array}$ & $\begin{array}{c}\text { DPPH } \\
\left(\mathrm{mmol}^{-1} \mathrm{~kg}^{-1}\right)\end{array}$ & $\begin{array}{c}\text { TBARS } \\
\mathrm{IC}_{50}\left(\mu \mathrm{m}^{-1}\right)\end{array}$ \\
\hline \multicolumn{4}{c}{ Harvest year 2007} \\
\hline Selection 07/001 & $48.5 \pm 2.9^{\mathrm{a}}$ & $15.2 \pm 0.1$ & $17.40^{\mathrm{a}}(10.70-28.30)$ \\
Selection 03/001 & $47.4 \pm 2.6^{\mathrm{a}}$ & $14.3 \pm 0.2$ & $28.38^{\mathrm{a}}(14.66-54.93)$ \\
Selection 02/96 & $57.2 \pm 1.1^{\mathrm{a}}$ & $14.6 \pm 1.0$ & $1.21^{\mathrm{b}}(0.62-2.35)$ \\
Guarani & $29.8 \pm 5.3^{\mathrm{b}}$ & $14.9 \pm 0.8$ & $23.99^{\mathrm{a}}(10.56-54.51)$ \\
Tupy & $33.6 \pm 0.6^{\mathrm{b}}$ & $15.3 \pm 0.3$ & $1.10^{\mathrm{b}}(0.32-3.79)$ \\
Cherokee & $53.8 \pm 2.8^{\mathrm{a}}$ & $15.0 \pm 0.7$ & $1.52^{\mathrm{b}}(0.62-1.71)$ \\
\hline & & Harvest year 2009 & \\
\hline Cherokee & $18.3 \pm 2.4^{\mathrm{b}, *}$ & $4.7 \pm 0.8^{*}$ & $0.16^{\mathrm{a}, *}(0.09-0.28)$ \\
Selection 99 & $24.5 \pm 2.2^{\mathrm{ab}}$ & $5.1 \pm 1.0$ & $0.06^{\mathrm{b}}(0.04-0.08)$ \\
Xavante & $32.3 \pm 1.1^{\mathrm{a}}$ & $4.5 \pm 0.7$ & $0.07^{\mathrm{ab}}(0.03-0.16)$ \\
\hline
\end{tabular}

FRAP and DPPH values are means \pm standard deviations $(n=3)$ expressed as mmol of trolox equivalent per $1 \mathrm{~kg}$ of fruit. The $I_{50}$ values are means (confidence intervals) $(n=3)$ expressed as $\mu \mathrm{g}$ of anthocyanins per $1 \mathrm{~mL}$ of extract. DPPH: 1,1-diphenyl2-picrylhydrazyl; FRAP: ferric reducing antioxidant power; TBARS: thiobarbituric acid reactive substances. Values that have no common superscript letter $(a, b)$ within the same column and in the same harvest year are significantly different $(p<0.05)$. *Significantly different from Cherokee in the harvest year $2007(p<0.05)$.

Concerning the TBARS assay, all genotypes inhibited lipid oxidation in a dose-dependent manner ( $p<0.05$; Fig. 2). In the harvest 2007, Cherokee and Tupy cultivars and selection 02/96, had higher antioxidant activity (lower $I C_{50}$ values) than the other genotypes $(p<0.05$; Table 3$)$. In the harvest 2009, selection 99 had greater potency to inhibit lipid oxidation (lower $\mathrm{IC}_{50}$ value) than Cherokee cultivar, whereas Xavante had intermediate potency $(p<0.05$; Table 3). Unlike the FRAP and DPPH assays, the Cherokee cultivar from 2007 had lower potency (higher $I C_{50}$ value) to inhibit lipid oxidation in the TBARS assay than the Cherokee cultivar from $2009(p<0.05$ Table 3).

To identify some compounds responsible for the antioxidant activity of the anthocyanic extracts, the anthocyanin and ascorbic acid content of the extracts were evaluated (Table 4) and its correlation with the antioxidant activity. No significant difference was found in the total anthocyanin content among genotypes. However, Cherokee cultivar from harvest 2009 had lower anthocyanin content that from the harvest $2007(p<0.05$; Table 4). Unlike the phenolic extracts, the anthocyanic extracts had significant amounts of ascorbic acid (Table 4). In the harvest 2007, the anthocyanic extracts from Guarani, Tupy and Cherokee cultivars had higher ascorbic acid content than the other genotypes $(p<0.05)$, whereas in the harvest 2009 selection 99 had higher ascorbic acid content than the other genotypes $(p<0.05)$. As observed for the anthocyanin content, Cherokee cultivars from 2009 also had lower ascorbic acid content than those from $2007(p<0.05)$. 


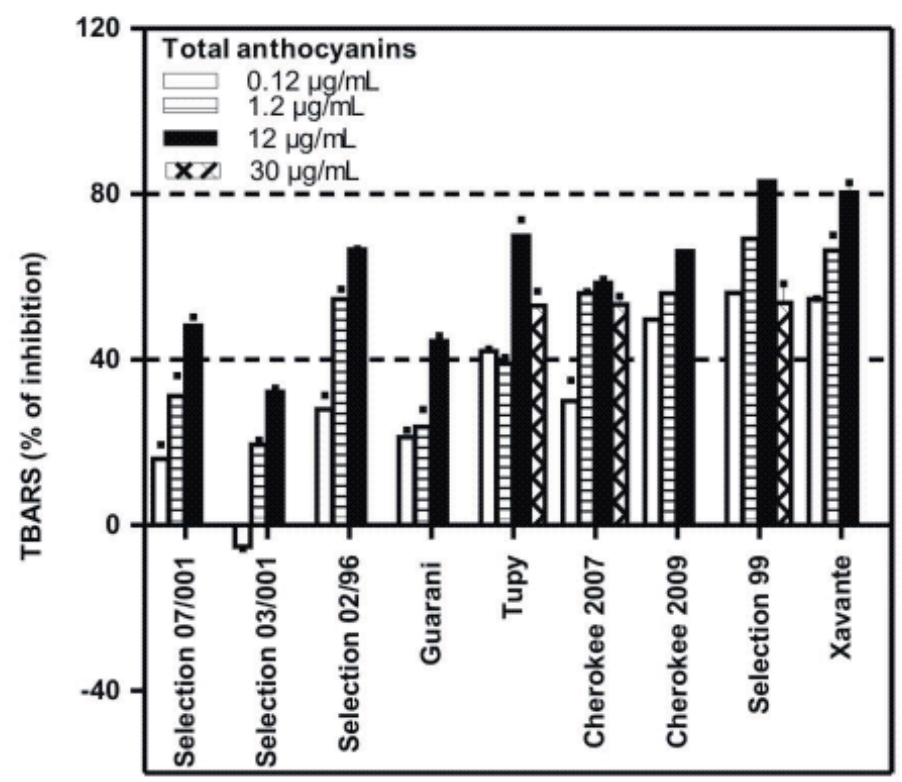

Blackberry genotypes

\section{FIGURE 2 - INHIBITION OF LIPID OXIDATION IN FISH HOMOGENATE BY BLACKBERRY ANTHOCYANIC EXTRACTS}

Results are expressed as means \pm standard deviations $(n=3)$. Two-way ANOVA revealed a significant anthocyanin concentration $x$ blackberry genotype interaction on the inhibition of lipid oxidation both in the harvest 2007 and 2009 $(p<0.05)$. The $\mathrm{IC}_{50}$ values are shown in Table 3.

TABLE 4 - COMPOSITION OF BLACKBERRY ANTHOCYANIC EXTRACTS

\begin{tabular}{lcc}
\hline Samples & $\begin{array}{c}\text { Total anthocyanins } \\
\left(\mathrm{g}^{-} \mathrm{kg}^{-1}\right)\end{array}$ & $\begin{array}{c}\text { Ascorbic acid } \\
\left(\mathrm{mg}^{*} \mathrm{~kg}^{-1}\right)\end{array}$ \\
\hline Selection 07/001 & $1.00 \pm 0.03$ & $21.0 \pm 3.8^{\mathrm{b}}$ \\
Selection 03/001 & $0.82 \pm 0.12$ & $18.1 \pm 0.9^{\mathrm{b}}$ \\
Selection 02/96 & $0.85 \pm 0.03$ & $20.4 \pm 1.0^{\mathrm{b}}$ \\
Guarani & $0.78 \pm 0.15$ & $35.3 \pm 1.9^{\mathrm{a}}$ \\
Tupy & $0.75 \pm 0.01$ & $34.5 \pm 1.9^{\mathrm{a}}$ \\
Cherokee & $0.68 \pm 0.10$ & $38.0 \pm 1.8^{\mathrm{a}}$ \\
\hline & Harvest year 2009 & \\
\hline Cherokee & $0.27 \pm 0.01^{*}$ & $9.0 \pm 0.3^{\mathrm{b}, *}$ \\
Selection 99 & $0.27 \pm 0.04$ & $21.9 \pm 0.7^{\mathrm{a}}$ \\
Xavante & $0.24 \pm 0.01$ & $10.8 \pm 0.1^{\mathrm{b}}$ \\
\hline
\end{tabular}

Results are means \pm standard deviations $(n=3)$. Values that have no common superscript letter $(a, b)$ within the same column and in the same harvest year are significantly different $(p<0.05)$. ${ }^{*}$ Significantly different from Cherokee in the harvest year $2007(p<0.05)$. 
The DPPH values were positively correlated both to the total anthocyanins $\left(r^{2}=0.921\right.$; $p<0.05)$ and ascorbic acid contents $\left(r^{2}=0.674 ; p<0.05\right)$. Since there was a tendency of a significant correlation between total anthocyanins and ascorbic acid content $\left(r^{2}=0.459 ; p=0.055\right)$, partial correlations between DPPH values and the content of these compounds were performed. Partial correlation revealed a positive correlation between DPPH and anthocyanins controlling for the ascorbic acid content $\left(r^{2}=0.931 ; p<0.05\right)$ and also a positive correlation between DPPH and ascorbic acid content controlling for the anthocyanins content $\left(r^{2}=0.724 ; p<0.05\right)$. Unlike the DPPH, the FRAP values were only correlated to the anthocyanins content $\left(r^{2}=0.728 ; p<0.05\right)$, whereas the antioxidant activity assessed by the TBARS assay was not correlated to the compounds analyzed (total anthocyanins and ascorbic acid).

\section{DISCUSSION}

Because of multiple reaction characteristics and mechanisms, a single antioxidant assay would not accurately reflect all antioxidants in a complex system like fruits and other foodstuffs (ANTOLOVICH et al., 2002). For this reason, four different antioxidant assays were used to evaluate blackberries from the major producer region of Brazil (temperate climate region). DPPH and FRAP assays are simple and rapid methods for assessing the antioxidant activity of fruits (ANTOLOVICH et al., 2002; BAGETTI et al., 2009; 2011). In the FRAP assay the antioxidant capacity is measured as the ability to reduce $\mathrm{Fe}^{3+}$-TPTZ complex to $\mathrm{Fe}^{2+}$-TPTZ complex (BENZIE \& STRAIN, 1996), whereas the DPPH assay involves a fast electron transfer from phenolic compounds to the DPPH radical (BRAND-WILLIAMS, CUVELIER \& BERSET, 1995; MARTINS et al., 2009). Despite some differences, the FRAP and DPPH antioxidant assays of phenolic extracts showed similar results, with selections 07/001 and 02/96 exhibiting the highest antioxidant capacity.

Although widely used in the screening of antioxidant compounds, the DPPH and FRAP assays are conducted at conditions far from those found in food systems or in the human body (ANTOLOVICH et al., 2002). In the DPPH assay, the free radical formed is synthetic, thus the antioxidant activity against biological radicals may not be the same as evaluated in this method. Moreover, DPPH assay does not detect pro-oxidant substances because it evaluates only the reducing power of the antioxidant (DUARTE-ALMEIDA et al., 2006). In the FRAP assay, the measurement of the reducing capacity does not necessarily reflects the antioxidant capacity (FRANKEL \& MEYER, 2000) because some antioxidants are not able to reduce iron and iron reducing agents are not always antioxidants (PRIOR et al., 2003).

In contrast, the $\beta$-carotene bleaching and the TBARS assay conditions are more similar to that found in food systems and thus give a clearer idea of the antioxidant properties of the compounds tested (ANTOLOVICH et al., 2002).

The $\beta$-carotene assay is based on the decay of $\beta$-carotene absorbance due to its competitive bleaching during the autoxidation of linoleic acid in aqueous emulsion (MILLER, 1971). An antioxidant attenuates $\beta$-carotene bleaching. The phenolic extracts from Guarani and Xavante cultivars had the highest inhibitory potency in this test (lower $\mathrm{IC}_{50}$ values), in the harvests 2007 and 2009, respectively. Hassimotto et al. (2008) did not find significant differences in the antioxidant activity among different blackberry genotypes including Tupy and Guarani in the $\beta$-carotene assay. However, these authors evaluated only the effect of one fixed amount of the extract, which is not appropriate to estimate and compare the inhibitory potency.

It was also measured the ability of phenolic extracts to inhibit iron-induced lipid oxidation in a fish flesh homogenate, which was assessed as TBARS formation. Selections 02/96 and 03/001 had the highest antioxidant activity in the TBARS assay, followed by selection $07 / 001$. Thus, except for selection 99, the blackberry selections showed higher antioxidant activities in this assay than the fruit cultivars. These data are interesting because the new selections developed by Embrapa seem to have greater antioxidant potential. 
No differences were verified in the antioxidant activity of phenolic extracts between Cherokee fruits from harvest 2007 and 2009, regardless of the antioxidant assay evaluated. However, the TBARS and $\beta$-carotene bleaching assays also have some limitations. In the TBARS assay, substances other than MDA (malondialdehyde) such as sugars and other aldehydes may also react with TBA and interfere with the reaction (ESTERBAUER et al., 1984). In addition, reducing or oxidizing substances interfere in $\beta$-carotene bleaching assay (FRANKEL, 1994).

The ability to scavenge reactive oxygen species depends on the type of antioxidant. Fruits contain many different antioxidant components and their relative quantities may also vary, affecting the total antioxidant capacity of fruits (SARIBURUN et al., 2010).

It was found significant differences in the total phenolic content among certain genotypes evaluated, which can be explained by genetic factors. Other authors found lower phenolic content in blackberries (about $2.1 \mathrm{~g}$ of gallic acid per $1 \mathrm{~kg}$ of fruit), but they evaluated different genotypes (WANG, BOWMAN \& DING, 2008). Only Tupy, Guarani and Cherokee cultivars had been previously evaluated. Tupy and Guarani cultivars grown in a tropical climate (central region of Brazil) presented slightly lower phenolic content ( 3.7 and $4.3 \mathrm{~g}$ of gallic acid per $1 \mathrm{~kg}$ of fruit, respectively) (HASSIMOTTO et al., 2008) than those found in the present study. Similar results were found for Cherokee cultivars grown in Turkey (3.0 g of gallic acid per $1 \mathrm{~kg}$ of fruit) (KOCA \& KARADENIZ, 2009). Thus, differences from previous studies may be due to soil and climate differences. In fact, it was proved that climate changes affect the phenolic content of blackberries (REYES-CARMONA et al., 2005). However, in the present study the total phenolic content of Cherokee fruits grown in the same place did not change between harvest 2007 and 2009. Similar results were found by Dai et al. (2009) who studied Hull blackberries from different years.

Quercetin was the only phenolic compound identified at relevant amount in the phenolic extracts of blackberry samples in the present study. It was found a wide variation in the amount of quercetin in blackberries from different genotypes, as previously reported (HASSIMOTTO et al., 2008). Among the cultivars evaluated in the present study, only Tupy and Guarani had been previously studied and presented higher quercetin values (78 and $133 \mathrm{mg}^{\cdot \mathrm{kg}^{-1}}$, respectively) (HASSIMOTTO et al., 2008) than those found in this study. However, the amount of quercetin found in this study is higher than that reported by the USDA database (2011) for blackberry.

Although this study focused mainly on the polyphenols found in blackberries, some phenolic extracts had a small amount of ascorbic acid. This finding is in agreement with a previous study that found only the oxidized form of vitamin C ( probably due to the fast oxidation of vitamin $\mathrm{C}$ and absence of synthesis of ascorbic acid during development or ripening (HASSIMOTTO et al., 2008).

Several authors demonstrated a strong positive correlation between total phenolic content and the antioxidant capacity of fruits (BAGETTI et al., 2011; SARIBURUN et al., 2010; VINSON et al., 1998) including blackberries (DAl et al., 2009; REYES-CARMONA et al., 2005). The correlations found between bioactive compounds and the antioxidant activity of phenolic extracts suggest that phenolic compounds are the major responsible for the antioxidant activity in the DPPH, FRAP and TBARS assays. However, quercetin which was the only phenolic compound that was identified and quantified in the present study does not seem to contribute to the antioxidant activity of the phenolic extracts in these assays (no significant correlation). Thus, it is possible that other phenolic compounds that appeared to be at much higher concentration than quercetin in the chromatograms, but could not be identified, are actually the major responsible for this activity.

The quercetin content of phenolic extracts was negatively correlated to the $\mathrm{IC}_{50}$ values for $\beta$-carotene bleaching, indicating that quercetin has a major contribution to this antioxidant activity. Although quercetin is a phenolic compound no relation was found between total phenolic content and the antioxidant activity in the $\beta$-carotene bleaching assay, possibly because other phenolic compounds that are quantified in the total phenolic assay, but were not identified in HPLC analysis, have no effect on this assay. The antioxidant activity of flavonoids is closely linked to its structure, 
such as the presence of an orto-dihydroxy or catechol group in the B ring, the conjugation of the B-ring to the 4-oxo group via the 2,3-double bond, the 3- and 5- $\mathrm{OH}$ groups with the 4-oxo group (SILVA et al., 2002). Quercetin shows all the structural characteristics mentioned above, which may explain the high antioxidant capacity of extracts of different genotypes of blackberry in the $\beta$-carotene bleaching system.

Regardless of the antioxidant assay, ascorbic acid seems to play no role in the antioxidant activity of phenolic extracts from blackberry genotypes, possibly due to its very low concentration in the blackberry extracts.

The antioxidant capacity of the anthocyanic extracts was evaluated only by the FRAP, DPPH and TBARS assays. In the FRAP assay, the selections 07/001, 03/001 and 02/96 and the Cherokee cultivar had the greatest ferric reducing power in the harvest 2007, whereas in the harvest 2009 Xavante cultivar had the greatest value. FRAP values found were lower than those previously reported for commercial blackberry cultivars from USA (SIRIWOHARN et al., 2004). This may have occurred due to several factors such as the differences in the method used to extract compounds, climatic or genetic differences, because these authors analyzed different genotypes. In the DPPH assay, no differences were found among genotypes. However, in the TBARS assay selection 02/96, Tupy and Cherokee cultivars had the greatest potency to inhibit lipid oxidation in the harvest 2007, whereas in the harvest 2009 selection 99 had the greatest potency followed by Xavante. The Cherokee cultivar from harvest 2007 had greater antioxidant capacity than that from 2009 both in the FRAP and in the DPPH assays, which is in line with its higher ascorbic acid and anthocyanin content. Interestingly, the opposite result was observed in the TBARS assay. Although ascorbic acid is usually an antioxidant due to its reducing capacity, it may catalyze the formation of hydroxyl radicals in the presence of transition metals, like iron (HALLIWELL \& GUTTERIDGE, 2007). Hydroxyl radicals are potent oxidants that may lead to lipid oxidation (HALLIWELL \& GUTTERIDGE, 2007). Thus, the higher content of ascorbic acid in Cherokee from 2007 could explain its lower antioxidant capacity against iron-induced lipid oxidation (TBARS assay), but the opposite result in the FRAP and DPPH assays.

Several health benefits of purple fruits, including antioxidant effects, are linked to the presence of anthocyanins (DAl et al., 2009; PRIOR, 2003). It was found higher anthocyanin content in the Cherokee cultivar from harvest 2007 compared to the 2009, suggesting a climate effect, since both fruits were grown at the same place and season, but in different years. Light is a major environmental factor in the control of anthocyanins production. Longer photoperiod and greater light intensity are known to increase anthocyanins levels in other plants (PARR \& BOLWELL, 2000). In fact, the duration of sunlight hours in 2007 was 1.3 to 2.4-fold higher than in 2009 during the fruit development and ripening periods (data from the Meteorological observer of Embrapa Temperate Climate). Other authors found higher amounts of anthocyanins $\left(1.16-7.92 \mathrm{~g}^{\prime} \mathrm{kg}^{-1}\right.$ fruit), however, they studied other genotypes (TOSUN, USTUN \& TEKGULER, 2008) that were grown in otherr regions (HASSIMOTTO et al., 2008; TOSUN, USTUN \& TEKGULER, 2008). Unlike the phenolic extracts, the anthocyanic extracts had relevant amounts of ascorbic acid, especially those from Guarani, Tupy and Cherokee cultivars in the harvest 2007 and from selection 99 in the harvest 2009.

The correlation tests revealed that anthocyanins are the major responsible for the FRAP and DPPH antioxidant activity of the anthocyanic extracts from blackberries. In addition, ascorbic acid also contributed to the DPPH antioxidant activity of these extracts. In contrast, the antioxidant activity assessed by the TBARS assay had no relationship with total anthocyanins or ascorbic acid content. The antioxidant potential of anthocyanins is affected by differences in their structural characteristics (PRIOR, 2003). Thus, differences in the composition and antioxidant activity of anthocyanins among the various genotypes evaluated could explain the absence of relationship between the total anthocyanin content and the TBARS assay.

For most genotypes the antioxidant capacity (DPPH, FRAP and TBARS values) of anthocyanic extracts were usually higher than that of the phenolic extracts. These data suggest a 
greater involvement of anthocyanins in the antioxidant activity of blackberries. In addition, these results may be also related to the method of extraction, because the anthocyanic extract was obtained after exhaustive extraction, what did not occur with the extraction of phenolic compounds. Concerning the genotypes studied, the selection 02/96 showed one of the highest antioxidant capacity assessed by the four different methods and was among the genotypes that had higher content of total phenolics and anthocyanins.

\section{CONCLUSION}

Regarding the phenolic extracts, selections $02 / 96$ and 07/001 had higher antioxidant activity than the cultivars in most assays, and this activity was partially correlated to the higher amount of total phenolics in these samples, indicating that phenolic compounds are probably the major responsible for the antioxidant activity in the DPPH, FRAP and TBARS assays. Quercetin seems to be responsible for the antioxidant activity of blackberry phenolic extracts in the $\beta$-carotene bleaching assay. Concerning the anthocyanic extracts, selection 02/96 and Cherokee cultivar from harvest 2007 had higher antioxidant activity in most assays. Anthocyanins appear to be the major responsible for the antioxidant activity of anthocyanic extracts in the DPPH and FRAP assays, although ascorbic acid also contributed to the DPPH antioxidant activity. It was not possible to identify the compound responsible for the TBARS antioxidant activity of anthocyanic extracts. The results of this study revealed that blackberries from different genotypes can be considered as good sources of bioactive compounds with high antioxidant activity. The new blackberry selections developed by Embrapa, especially selection 02/96, appears to have higher antioxidant activity than the commercial cultivars cultivated in the southern Brazil. Thus, this selection appears to be promising for nutritional and health purposes.

\section{RESUMO}

\section{ATIVIDADE ANTIOXIDANTE DE GENÓTIPOS DE AMORA-PRETA (Rubus sp.) DA REGIÃO SUL DO BRASIL}

A atividade antioxidante e os compostos bioativos de diferentes genótipos de amora-preta da principal região produtora do Brasil (três cultivares e quatro seleções) foram analisados e comparados com a cultivar Cherokee. Foram obtidos e avaliados extratos fenólicos e antociânicos de cada genótipo de fruta. Os extratos fenólicos das seleções 02/96 e 07/001 apresentaram maior atividade antioxidante em comparação com as cultivares na maioria dos ensaios, a qual se mostrou parcialmente correlacionada com a maior quantidade de fenólicos totais nessas amostras. Os compostos fenólicos são, provavelmente, os principais responsáveis pela atividade antioxidante verificada nos ensaios de remoção do radical 2,2 difenil-1-picrilidrazila (DPPH), poder antioxidante de redução do ferro (FRAP) e de substâncias reativas ao ácido tiobarbitúrico (TBARS). A quercetina parece ser a responsável pela atividade antioxidante dos extratos fenólicos de amora-preta pelo ensaio de branqueamento do $\beta$-caroteno. Em relação aos extratos antociânicos, a seleção 02/96 e a cultivar Cherokee da safra de 2007 apresentaram maior atividade antioxidante que os outros genótipos na maioria dos ensaios. As antocianinas parecem ser as principais responsáveis pela atividade antioxidante dos extratos antociânicos conforme os ensaios DPPH e FRAP, embora o ácido ascórbico também tenha contribuído para a atividade antioxidante verificada pelo ensaio DPPH. A seleção 02/96 parece ter maior atividade antioxidante que as cultivares comerciais cultivadas no sul do Brasil, sendo promissora para fins nutricionais e de saúde.

PALAVRAS-CHAVE: EXTRATO DE FRUTA; ANTIOXIDANTES; POLIFENOIS; ANTOCIANINAS; ÁCIDO ASCÓRBICO.

\section{REFERENCES}

1 ANTOLOVICH, M. et al. Methods for testing antioxidant activity. The Analyst, v. 127, p. 183-198, 2002.

2 ANTUNES, L. E. C. Blackberry: a new crop option to Brazil. Ciência Rural, v. 32, p. 151-158, 2002. 
3 BAGETTI, M. et al. Antioxidant capacity and composition of pitanga seeds. Ciência Rural, v. 39, p. 2504-2510, 2009.

4 BAGETTI, M. et al. Physicochemical characterization and antioxidant capacity of pitanga fruits (Eugenia uniflora L.). Ciência e Tecnologia dos Alimentos, v. 31, p. 147-154, 2011.

5 BENZIE, I. F. F.; STRAIN, J. J. The ferric reducing ability of plasma (FRAP) as a measure of antioxidant power: the FRAP assay. Analytical Biochemistry, v. 239, p. 70-76, 1996.

6 BRAND-WILLIAMS, W.; CUVELIER, M. E.; BERSET, C. Use of a free radical method to evaluate antioxidant activity. Food Science and Technology, v. 28, p. 25-30, 1995.

7 BRAVO, L. Polyphenols: chemistry, dietary sources, metabolism, and nutritional significance. Nutrition Reviews, v. 56, p. 317-333, 1998

8 CUEVAS-RODRÍGUEZ, E. O. et al. Characterization of anthocyanins and proanthocyanidins in wild and domesticated Mexican blackberries (Rubus spp). Journal of Agricultural and Food Chemistry, v. 58, p. 7458-7464, 2010.

9 DAI, J. et al. A comprehensive study of anthocyanin-containing extracts from selected blackberry cultivars: extraction methods, stability, anticancer properties and mechanisms. Food and Chemical Toxicology, v. 47, p. 837-847, 2009.

10 DUARTE-ALMEIDA, J. M. et al. Avaliação da atividade antioxidante utilizando sistema $\beta$-caroteno/ácido linoléico e método de seqüestro de radicais $\mathrm{DPPH}^{+1}$. Ciência e Tecnologia dos Alimentos, v. 26, p. 446-452, 2006.

11 ELISIA, I. et al. Antioxidant assessment of an anthocyanin-enriched blackberry extract. Food Chemistry, v. 101, p. 10521058, 2007.

12 ESCARPA, A.; GONZALEZ, M. C. Approach to the content of total extractable phenolic compounds from different food samples by comparison of chromatographic and spectrophotometric methods. Analytica Chimica Acta, v. 427, p. 119127, 2001.

13 ESTERBAUER et al. Detection of malonaldehyde high performance liquid chromatography. Methods in Enzymology, v. 105, p. 319-328, 1984

14 FRANKEL, E. N.; MEYER, A. S. The problem of using onedimensional methods to evaluate multifunctional food and biological antioxidants. Journal of the Science of Food and Agriculture, v. 80, p.1925-1941, 2000.

15 FRANKEL, E. N. et al. Interfacial phenomena in the evaluation of antioxidants: bulk oils vs emulsions. Journal of Agricultural and Food Chemisty, v. 42, p. 1054-1059, 1994.

16 HALLIWELL, B.; GUTTERIDGE, J. M. C. Free radicals in biology and medicine. $4^{\text {th }}$ ed. New York: Oxford University Press, 2007. $704 \mathrm{p}$.

17 HASSIMOTTO, N. M. A. et al. Physico-chemical characterization and bioactive compounds of blackberry fruits (Rubus sp.) grown in Brazil. Ciência e Tecnologia dos Alimentos, v. 28, p. 702-708, 2008.

18 KOCA, I.; KARADENIZ, B. Antioxidant properties of blackberry and blueberry fruits grown in the Black Sea Region of Turkey. Scientia Horticulturae, v. 121, p. 447-450, 2009.

19 LEES, D. H.; FRANCIS, F. J. Standardization of pigment analyses in cranberries. Hortscience, v. 7, p. 83-84, 1972.

20 MARTINS, D. M. et al. Antioxidant potential of new pyrazoline derivatives to prevent oxidative damage. Basic and Clinical Pharmacology and Toxicology, v. 104, p. 107-112, 2009.

21 MILLER, H. E. A simplified method for the evaluation of antioxidants. Journal of the American Oil Chemists' Society, v. 45, p. $91,1971$.

22 MOLLER, J. K. S. et al. Dittany (Origanum dictamnus) as source of water extractable antioxidant. Food Chemistry, v. 64, p. 215-219, 1999.

23 MOTULSKY, H.; CHRISTOPOULOS, A. Fitting models to biological data using linear and nonlinear regression: a practical guide to curve fitting. New York, NY: Oxford University Press, 2004. 352 p.

24 PARR, J. A.; BOLWELL, G. P. Phenols in the plant and in man. The potential for possible nutritional enhancement of the diet by modifying the phenols content or profile. Journal of the Science of Food and Agricultural, v. 80, p. 985-1012, 2000.

25 PELLEGRINI, N. et al. Evaluation of antioxidant capacity of some fruit and vegetable foods: efficiency of extraction of a sequence of solvents. Journal of the Science of Food and Agricultural, v. 87, p. 103-111, 2007.

26 PRIOR, R. L Fruits and vegetables in the prevention of cellular oxidative damage. The American Journal of Clinical Nutrition, v. 78, p. 570S-578S, 2003. 
27 REYES-CARMONA, J. et al. Antioxidant capacity of fruit extracts of blackberry (Rubus sp.) produced in different climatic regions. Journal of Food Science, v. 70, p. 497-503, 2005.

28 SÁNCHEZ-MATA, M. C. et al. Comparison of high-performance liquid chromatography and spectrofluorimetry for vitamin C analysis of green beans (Phaseolus vulgaris L.). European Food Research Technology, v. 210, p. 220-225, 1999.

29 SARIBURUN, E. et al. Phenolic content and antioxidant activity of raspberry and blackberry cultivars. Journal of Food Science, v. 75, p. 328-335, 2010.

30 SEERAM, N. P. et al. Blackberry, black raspberry, blueberry, cranberry, red raspberry, and strawberry extracts inhibit growth and stimulate apoptosis of human cancer cells in vitro. Journal of Agricultural and Food Chemistry, v. 54, p. 9329-9339, 2006

31 SILVA, M. M. et al. Structure-antioxidant activity relationships of flavonoids: a re-examination. Free Radical Research, v. 36, p. 1219-1227, 2002.

32 SINGLETON, V. L.; ROSSI, J. A. Jr. Colorimetry of total phenolic with phosphomolybdic-phosphotungstic acid reagents. American Journal of Enology and Viticulture, v. 16, p. 144-158, 1965

33 SIRIWOHARN, T. et al. Influence of cultivar, maturity, and sampling on blackberry (Rubus L. Hybrids) anthocyanins, polyphenolics, and antioxidant properties. Journal of Agricultural and Food Chemistry, v. 52, p. 8021-8030, 2004.

34 SPIEGEL, M.; STEPHENS, L. Schaums outline of statistics. New York, NY: McGraw-Hill, 2011.600 p.

35 TOSUN, I.; USTUN, N. S.; TEKGULER, B. Physical and chemical changes during ripening of blackberry fruits. Scientia Agricola, v. 65, p. 87-90, 2008.

36 US Department of Agriculture. USDA database for the flavonoid content of selected foods, release 2.1. Beltsville, January 2007. Available on: <http://www.ars.usda.gov/Services/docs.htm?docid=6231. Accessed at: 22 June 2012.

37 VINSON, J. A. et al. Phenol antioxidant quantity and quality in foods: vegetables. Journal of Agricultural and Food Chemistry, v. 46, p. 4113-4117, 1998.

38 WANG, S. Y.; BOWMAN, L.; DING, M. Methyl jasmonate enhances antioxidant activity and flavonoid content in blackberries (Rubus sp.) and promotes antiproliferation of human cancer cells. Food Chemistry, v. 107, p. 1261-1269, 2008.

\section{ACKNOWLEDGEMENTS}

G.E. Hirsch received a CNPq Master Degree Fellowship. T. Emanuelli and A.T. Henriques were the recipients of CNPq Research Fellowships. This work was supported by Embrapa Clima Temperado, Edital Capes no. 11/2009 (Pró-Equipamentos Institucional), Edital Casadinhos (FAPERGS/CAPES) e Edital Casadinho/ PROCAD (CNPq). 